\title{
The main features of the economic ethics of European paganism
}

\author{
Evgeny Orlyansky \\ Omsk Humanitarian Academy,2a $4^{\text {th }}$ Cheluskintsev st., 644105 Omsk, Russia
}

\begin{abstract}
This article is devoted to the study of the main distinguishing features of the economic ethics of religious and mythological systems of the main ancient ethnic groups of Europe in the pagan era. The economic ethics of these systems is the very first foundation of the Christian economic ethics that dominated in the traditional market economy. It formed the basis for its development in ancient philosophy and, then, in Christianity. This economic ethics is most clearly expressed in ancient Greek mythology. But it is not limited to this, and its main features are also present in the religious and mythological systems of other European ethnic groups (Scandinavians, Celts, Balts, Slavs), which gives it the universal character.
\end{abstract}

\section{Introduction}

The spiritual foundations of business ethics have a very long history. There are alternative versions of this ethic in the modern economy. There is a well-known variant that prevails in the modern market economic system. This option, as you know, corresponds to the ideology of "economism". Another option is religious economic ethics, which is associated with the views of Christianity on economic processes and which became widely known thanks to Max Weber and Werner Sombart $[1,2]$. This economic ethic dominated in the traditional economy. However, it is obvious that this version of economic ethics has deeper foundations than Protestantism and even Christianity in general [3-5]. Christian economic ethics can be traced to the economic ethics of ancient philosophy (early Christian theologians, in general, carefully studied the ancient philosophical heritage). Indeed, the leading ancient Greek philosophers substantiated many theses of the future Christian economic ethics. For example, the idea of a purely pragmatic and subordinate attitude to the economy in society (without elements of its sacralization and with its subordination to noneconomic spiritual values) and the division of types of economic activity with the assignment of positive or negative estimations. However, there is reason to believe that the deepest foundations of economic ethics are not limited to the views of ancient philosophers in the field of economics. These foundations go deep into the ancient pagan beliefs of European ethnic groups. In addition, it should be noted that the economic ethics of ancient philosophy has been fairly well researched. On this background, much less attention is paid to the economic ethics of European paganism. This is what makes research in this area relevant and important. Research in this area will help to create a coherent picture of the 
formation of the Christian economic ethics of traditional economics. This is relevant in the period of current crisis of economic ethics based on "economism"[6].

\section{Materials and methods}

The main research method is the method of comparative analysis. The main sources for the analysis were research materials on the mythology of the ancient Greeks, Scandinavians, Celts and Slavs.

\section{Results and discussion}

As you know, ancient philosophy (first of all, Aristotle and Xenophon) orients the traditional ancient Greek society to recognize only the subordinate narrowly pragmatic nature of economic activity. It also puts forward hierarchy of types of economic processes and gives them positive and negative estimations (suffice it to recall Aristotle's famous opposition of "economics" and "chrematistics"). At the same time, this activity was measured and appreciated in terms of moral and ethical parameters. These parameters were the spiritual directions of the ancient Greek ethnos, which considered economic activity as forced, even in some ways, again, sacrificial. It was intended only to provide a material basis for the implementation of "noble" "spiritually grounded" activities - science, art, government, military service. The economy could in no way define the non-economic spheres of the life of society. There is nothing in such a philosophical system to confirm the historical character of the ideology of "economism". On the contrary, there are all reasons here to recognize the deep historical foundations of the alternative economic ethics that we are used to associate with Christianity (and Islam).

However, on the other hand, there is no reason to believe that all this was the result of the personal opinion of ancient philosophers. This cannot be considered their innovation. It can be assumed that the position of ancient philosophy in the field of economics themselves had their foundations in the more ancient spiritual traditions of ancient Greek society. These foundations were religious and mythological ideas of the ancient Greeks, which were the primary reflection of these spiritual traditions. Moreover, it should be borne in mind that religious directions in ancient society, in general, did not exert a dominant influence on ethical and philosophical systems. On the contrary, they often reflected the state of these systems. The question about the attitude towards economic life was, however, an exception to the general rule.

Analysis of ancient mythology gives grounds for counting. It should be noted that at least no sacred character was attached to economic activity. We do not see in this mythology any regulation of economic life (as, for example, in the Old Testament). This already suggests that in the ancient Greek religious and mythological tradition, economics is also attached exclusively subordinate importance in the life of society. We see only the traditional for most pagan religious and mythological systems, the tradition of patronage of one or another deity, one or another type of economic activities. It is in this tradition that the foundations are laid for the gradation of types of economic activity from the standpoint of positive and negative estimations. The most striking example of such a gradation was the opposition of such ancient Greek deities as Hermes and Hephaestus. Hermes was known to be the patron of trade and wealth in general. It is known that the myths ascribe purely negative personal qualities to Hermes. Simply put, he was associated with theft, deceit, deception. In the end, he became the patron of theft (remaining the patron of trade). In ancient Greek mythology, the behavior of Hermes bore traits of pragmatism and prudence (for example, the myth of Perseus and Andromeda) and was subjected to at least ridicule, at 
most condemnation. In the modern encyclopedia of ancient mythology, this aspect of this deity is described as follows: "Hermes's cunning and dexterity make him the god of trade and at the same time - the patron of deceit and theft, for who better than Hermes knows where and what lies badly and how best to hide the stolen ...". Description of the thieving exploits of Hermes and the story of the theft by the baby of a beautiful herd of cows from Apollo is given in Homer's "Hymn to Hermes" [7]. In the same "Odyssey", the most delicate orders of Zeus are performed by Hermes. Moreover, Hermes taught trickery his son Autolycus - Odysseus's grandfather on the mother's side. Autolycus, as you know, became the direct patron saint of thieves. Hence the cunning of Odysseus (on the verge of cheating). It is the result of direct inheritance from a divine ancestor [7]. In the context of the topic under discussion, the attitude of ancient Greek religious mythology to trade is very indicative. It (as an activity aimed at generating of additional income, and not at satisfying needs, according to ancient philosophers) was strongly associated and even often identified with purely criminal activity (theft). Simply put, extracting this additional income (trading profit) is associated with stealing. It should be borne in mind that this is not a society where a natural economy is dominated. On the contrary, we are talking about a religious and mythological system of society where, for the first time in the Ancient World, trade takes the place of one of the leading sectors of the economy. However, the spiritual tradition did not accept trade as an "honorable" kinds of economic activity. Note also that this point of view is confirmed by the evolution of the estimation of Hermes in the ancient Greek religious and mythological system. Thus, the main researcher of the image of Hermes in the archaic period, a representative of the Historical School, Wilhelm Rosher, did not find his negative estimations in this historical era [8]. In this era, trade still occupied leading positions in the economy of Ancient Greece, and it remained largely natural. The penchant for theft and deception began to be attributed to Hermes during the classical period of ancient Greek history. It was then that trade took leading positions in the economy, and Hermes became its patron (at the same time becoming the patron of thieves).

This is especially felt when analyzing the religious and mythological attitude, for example, to craft. As you know, the role of the patron saint of crafts in the ancient Greek religious and mythological system was assigned to Hephaestus. Hephaestus had an unpleasant appearance and this can be considered as a reflection of the attitude towards the economy as a whole, as a "base" and "forced" type of activity (in comparison with science, art, etc.). But Hephaestus's estimates were an order of magnitude higher than Hermes's. No negative moral traits were attributed to Hephaestus. And this already reflected more acceptable attitude towards the craft, compared to trade. Handicraft production was recognized, although, we repeat, rather "base", but a necessary and even, to a certain extent, a respected type of activity within the economy itself. This is understandable. It was the craft that was perceived as the Aristotelian "economy" focused on satisfying natural needs. And this was in stark contrast to commercial trading, as an element of "chrematistics", focused on maximizing profits as the ultimate target. It should be borne in mind that the ancient religious system did not imply a sharp distinction between divine and earthly life. Everyday life and life of the Olympic "gods" were a reflection of earthly processes. The character and behavior of the "gods" shown in the ancient Greek religious and mythological system reflected certain aspects of social life and their estimation by people themselves.

The ancient Greek religious and mythological system is the most developed such system among European ethnic groups, in which the economic ethics characteristic of the traditional economy as a whole is clearly manifested. But, fundamentally, similar ideas are contained in other religious and mythological systems of Europe, which in some way affect the issues of economic life. So, for example, analogues of Hermes are found in other such religious and mythological systems. It is well known that the ancient Greek pantheon of deities was almost completely adopted by ancient Roman mythology and Hermes became 
the prototype of Mercury (just as Hephaestus becomes the prototype of the ancient Roman Vulcan). The Celts and the Scandinavians (Loki) had similar deities. And these deities received about the same negative moral estimations as Hermes. In addition to the fact that in these ancient religious and mythological systems, economic life was also very weakly reflected, it also received a classification hierarchical estimation (where it did receive some kind of reflection) similar to the ancient Greek one. In the most developed religious and mythological systems, the economic aspect was represented by approximately the same scheme.

If we take one of the most developed ancient religious mythologies - Scandinavian, then all this is seen very clearly. Neither in the Edda, nor in Beowulf, nor in the Welsung Saga, do we not find serious reflections about economic life, even, for example, of the same regulatory character. Again, at best, they contain a mention about the patronage of a particular deity to a certain type of economic activity. It is worth noting that even the idea of divine patronage of economic activity did not appear in Scandinavian mythology immediately. In early Scandinavian paganism, there was not even an emphasis on the patronage of economic life in a separate divine personification. And only later a special patron of the craft (again, blacksmithing) appeared. It was Welund, the Scandinavian counterpart of Hephaestus. Even outwardly, he resembled Hephaestus (the same repulsive appearance, lameness). But, like Hephaestus, Welund had purely positive moral estimations. Especially in comparison with the image of Loki (which, as already mentioned, was an analogue of Hermes). This showed the special role of blacksmithing in traditional society. The image of Welund as the patron of crafts and blacksmithing was also present in Anglo-Saxon religious mythology and was transferred to Britain during the period of the Anglo-Saxon conquest, where it retained this its importance (as a patron of crafts and blacksmithing) until the spread of Christianity there.

At the same time, as already mentioned, a special attitude to economic life was not at all expressed in Scandinavian mythology, even in terms of regulatory content. This applied to both the early and late pagan periods. However, in the late pagan period, a technique appeared in Scandinavian mythology, which also reflected the attitude towards the economy in society. This is the so-called divine triad, which reflected the hierarchy of types of activities in Old Norse society. Scandinavian myths indicate that one of the elements of the divine triad, Freyr, is the patron saint of wealth and fertility. The most important thing is that in this highest divine triad he occupied a subordinate place in comparison with Odin the patron of military affairs and Thor - the patron of political and legal power [9]. Accordingly, the level of worship of this deity was significantly less than Odin and Thor. This emphasizes the role of the economy as a material basis for "honorable" and "noble" kinds of activities for the ancient Scandinavians - military art and political activity. At the same time, just like in Ancient Greece, only production, and not trade, was given a positive estimation. And this was again on the background of the fact that in the Viking Age the Scandinavians were already quite familiar with trading activities.

The situation is similar in the Celtic ethno-religious tradition. And here we also cannot explain this exclusively by the natural type of the Celtic economy. The economic relations of the Celtic tribes back in the III-I centuries BC were at a fairly high level. This is evidenced, at least, by the developed minting of coins. Celtic gold and silver coins spread during the indicated period from the Danube to Central Gaul, and the Belgs spread them in Britain [10]. In the Celtic pantheon, there is the famous triad of the "three gods of the craft" (Goibniu, Kredne and Luhta). Goibniu and Kredne were patrons of blacksmithing. Goibniu was also often depicted as the deity of builders and doctors. In this capacity, his image entered earlier Christianity in Ireland. The third representative of this triad, Luhta, was a famous carpenter deity [11]. This suggests that in Celtic society, craft played the role of the core of economic life and had positive moral estimations. Trade also did not receive any 
positive ratings. And, accordingly, no special (especially sacred) significance was attached to any types of economic life in the Celtic religious and mythological system.

A similar situation developed in the religious and mythological systems of the Balts. Blacksmithing also occupies a special place in the religious beliefs of the ancient Balts. So, in Lithuanian mythology there was also a special deity, Kalvaitis, who was the patron of blacksmiths [12]. Again, this deity had positive estimations in Lithuanian mythology, as evidenced by the presence of diminutive pet versions of his name. In Lithuanian mythology, special divine patrons of agriculture and agriculture are also distinguished. First of all, this role was played by Lauksargis. Lithuanian myths attributed this deity to the meaning of "keeper of the fields". Later, researchers interpreted this as an awareness of the need to protect property in the agriculture of the Baltic tribes.

Finally, the economic aspect in the ancient Slavic religious systems is based on a similar principle. So, on the island of Rugen there was also a triad of "divine patrons" of economic life, reminiscent of the Celtic system. Only the Slavic deities of the island, Ruevit, Yarovit and Porevit, were the patrons of agriculture and identified the various stages of the production process. In principle, this triad of deities was generally very revered on Rugen (the first two deities were also deities of war). This shows a respectful attitude to agriculture as a type of real economy. On the one hand, this is understandable, since agriculture was the backbone of the island economy. But, on the other hand, despite the extensive trade relations of the inhabitants of the island, trade did not receive such an attitude in the religious and mythological tradition. In the Eastern European religious and mythological tradition, a similar tendency of economic ethics is also repeated. There was a special patron of the blacksmith's craft - the deity Svarog in this version of the Slavic pantheon [13]. Again, Svarog was one of the main deities of the Eastern Slavs before the adoption of Christianity. Other crafts also received their patrons. So, Mokosh (female deity) patronized weaving and spinning. Agriculture, which was patronized by Veles, also had positive moral estimations. Trade, again, did not receive its patrons in the East Slavic pagan pantheon.

\section{Conclusion}

The attitude of ancient philosophy to economics was not an innovation of its authors. It was based on the spiritual tradition of ancient Greek pagan religious mythology.

Ancient Greek religious mythology also emphasizes the pragmatic and subordinate nature of the economy in society (the religious and mythological texts of the ancient Greeks do not impart sacredness to the economy and contain the regulation of economic processes, like the Old Testament). In addition, the ancient Greek religious and mythological system gives a gradation of the types of economics, giving them positive and negative moral estimations (through a positive or negative image of a patron deity).

This tradition was typical for other religious and mythological systems of ancient European ethnic groups (Scandinavians, Celts, Balts and Slavs). This speaks about the universal and integral nature of the economic ethics of European paganism.

\section{References}

1. W. Sombart, Jews and economic life, 624 (2004)

2. M. Weber, Protestant ethics and the spirit of capitalism, 656 (2017)

3. D. Baur, F. Birke, J. Fehling, J Bus Ethics, 80, 279 (2008)

4. M. Borowski, Int Rev Econ, 66, 265 (2019) 
5. H.Y. Lin, J Bus Ethics, 121, 189 (2014)

6. E.A. Orlyansky, Science of person: humanitarian researches, 2, 186 (2019)

7. Ancient mythology, 768 (2004)

8. W.H. Roscher, Hermes der Windgott, 148 (2017)

9. Scandinavian mythology, 592 (2004)

10. T. Powell, Celts, 236 (2004)

11. T. Rolleston, Myths, legends and traditions of the Celts, 349 (2004)

12. M. Gimbutas, Balty, 233 (2004)

13. M. Gimbutas, Slavs, 216 (2005) 